\title{
La persona y siempre la persona
}

Fernando Herrero

Presidente de la Academia de la Publicidad

Cuando hablamos de las nuevas tecnologías, de los nuevos medios de comunicación comercial, nos apartamos del hombre cotidiano utilizando un lenguaje complejo, raro, poco entendible. Veámoslo desde otro punto de vista, desde el lado de la gente, de las personas, de los que consumen.

Tradicionalmente, los profesionales de la comunicación comercial hemos ido inventando técnicas para conocer al consumidor. La investigación trataba, de forma bastante artificiosa, de averiguar todo a cerca de todos aquellos que consumían, que compraban para ellos o quienes lo hacían para otros.

Las variadas técnicas nunca me gustaron (precisamente por lo artificiosas que eran) y los resultados menos. Recuerdo hacer un pretest de campaña con diez personas y sacar la conclusión de que casi el $90 \%$ del target comprarían ese producto tras la campaña de publicidad.

Las propias definiciones de targets eran de risa: mujeres de entre 20 y 50 años que viven en ciudades de más de 100.000 habitantes y de clase media. Vamos, que esa campaña iba perfectamente dirigida a todas las mujeres....Como este, hay multitud de ejemplos como para sonreír o sonrojarse....

El consumidor es un montón de personas variopintas con algún rasgo en común y multitud de diferencias. Somos tan diferentes uno del otro como las huellas digitales. 
Los únicos publicitarios que no se confundían eran los que usaban el sentido común y la experiencia, que unidos nos llevaban por el camino de lo razonable hasta enamorar a la persona.

Cuando han aparecido las nuevas tecnologías y, concretamente, con la explosión de las redes sociales ha ocurrido el milagro: lo artificial (la tecnología) ha conseguido que podamos conocer a las personas de verdad porque son ellos mismos los que nos cuentan como son.

Veníamos diciendo año tras año que el consumidor era el rey: ¡mentira! $\mathrm{Al}$ consumidor lo modelábamos de acuerdo con lo que el anunciante (la marca) quería. Le dábamos los valores de una gran marca y le decíamos: «Si usas esa marca, tú serás como ella».

Utilizábamos todas las fórmulas para que se creyeran los amos y lo único que hacían era seguir los dictados de las marcas.

Ahora el poder del consumidor es muy cierto porque tiene la capacidad de conocer tan afondo como quiera la realidad de una compañía, de hablarle de tú a tú, de enfrentarse a ella solo o en grupo y de decirle lo buena o mala que es.

Cada día la gente traga menos. El conocimiento que tiene y la capacidad de presión que se puede ejercer en las compañías para que cambien son más y más grandes.

Queda mucho camino por recorrer pero se equivoca quien piensa que ha sido la tecnología quien ha cambiado. Sobre todo es la gente, las personas quienes lo han hecho.

Podemos aprender de lo mal que lo hacen los políticos. En sus campañas, nos contaban lo buenos que eran y lo malo, malísimos sus adversarios. Íbamos a votar creyendo aproximadamente lo que nos decían.

Ahora las cifras de abstención van a más porque vemos la distancia entre lo que hacen cada día y lo que nos cuentan en sus campañas. Las redes sociales arden con las noticias que aparecen sobre ellos. Nadie se puede esconder y acaba sabiéndose todo y por todos.

La manera de comunicar ahora es diferente y lo es porque el consumidor exige más verdad, más proximidad, más transparencia, más honestidad...

El caso es que este vuelco tremendo no ha hecho más que empezar aunque las consecuencias las han notado duramente algunas empresas: petroleras que se las daban de ecologistas han caído en bolsa al saberse lo que contaminaban, bancos que han desaparecido cuando se ha conocido el tipo de gestión que han hecho, políticos repudiados....

Hay que trabajar con el consumidor para el consumidor y no solo en mejorar los productos. Importa la gestión medioambiental, los precios justos, la política de personal o de proveedores, la igualdad de la mujer, el consumo razonable, la 
responsabilidad corporativa, la conciliación....Todo es susceptible de utilizarse a favor o en contra de una marca o de una compañía.

El consumidor sabe lo que quiere y lo que puede hacer.

Soy presidente de la Academia de la Publicidad y consultor.

Cuando me piden consejo suele ser en clave de comunicación comercial y lo cierto que casi siempre acabo trabajando para dar sentido a esa compañía en la actualidad, para que dure 100 años. Porque pensar a corto plazo significa ganar dinero rápido a costa del consumidor sin darnos cuenta que más pronto que tarde nos harán pagar caro el engaño.

Hay compañías que lo hacen bien y otras que se van incorporando a este nuevo pensamiento. El que quiera seguir en el mercado tendrá que cambiar.

\section{Referencia de este artículo}

Herrero, Fernando (2014). La persona y siempre la persona. En: adComunica. Revista Científica de Estrategias, Tendencias e Innovación en Comunicación, $n^{\circ}$ 8. Castellón: Asociación para el Desarrollo de la Comunicación adComunica, Universidad Complutense de Madrid y Universitat Jaume I, 205-207. DOI: http://dx.doi.org/10.6035/2174-0992.2014.8.11. 
